\begin{tabular}{|c|c|}
\hline 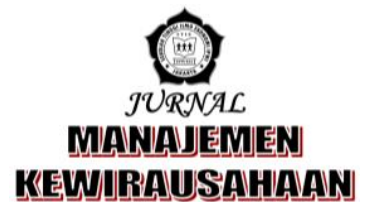 & $\begin{array}{r}\text { p-ISSN 1858-1048 } \\
\text { eISSN 2654-9247 } \\
\text { http://ejurnal.stieipwija.ac.id/index.php/imk } \\
\text { DOI: http://dx.doi.org/10.33370/jmk.v16i2.345 } \\
\text { Jurnal Manajemen Kewirausahaan Vol. 16 No. 02 - Desember } 2019 \\
\text { Submit: } 30 \text { Nov 2019; Review: 05 Des 2019; Publish: 30 Des } 2019\end{array}$ \\
\hline
\end{tabular}

\title{
DAMPAK MEDIA PROMOSI ONLINE, BRAND IMAGES DAN HARGA TERHADAP KEPUTUSAN MENJADI MAHASISWA
}

\author{
Oleh: \\ Idham Maulana Oktora'), Yoyo Indah Gunawan ${ }^{2)}$ \\ idhamaulanaoktora@gmail.com ${ }^{1)}$, yiguna.YG@gmail.com $\left.{ }^{2}\right)$ \\ Sekolah Tinggi Ilmu Ekonomi IPWI Jakarta ${ }^{1,2}$
}

\begin{abstract}
ABSTRAK
Penelitian Dampak Media Promosi Online, Brand Images dan Harga terhadap Keputusan Menjadi Mahasiswa Program Sarjana Manajemen Sekolah Tinggi Imu Ekonomi IPWI Jakarta ini bertujuan untuk mengetahui dampak dari masing-masing variabel terhadap keputusan menjadi mahasiswa. Sampel yang diambil dari populasi yang ada menggunakan rumus slovin didapat jumlah sebanyak 100 responden. Teknis analisis pada penelitian ini menggunakan uji validitas, uji reliabilitas, uji asumsi klasik, uji regresi berganda, analisis determinasi, dengan menggunakan uji hipotesis, yaitu uji $F$ dan Uji $t$. Hasil analisis persamaan regresi berganda adalah $Y=2,896+0,107 X 1+$ 0,498 X2 + 0,317 X3 dengan arti koefisien regresi dampak Promosi Media Online bernilai positif sebesar 0,107, koefisien regresi Brand Images bernilai positif sebesar 0,498, koefisien regresi Harga bernilai positif sebesar 0,317, hal ini menunjukkan bahwa seluruh variabel independen berdampak positif terhadap variabel dependen yaitu keputusan menjadi Mahasiswa STIE IPWIJA. R Square (R2) sebesar 0,671. Hal ini menunjukan bahwa sebesar 67,1 \% Variabel Media Promosi Online, Brand Images dan Harga secara simultan berdampak terhadap Keputusan Menjadi Mahasiswa, sedangkan sisanya 32,9 \% karena faktor lain yang tidak di teliti pada penelitian ini seperti lokasi, pelayanan, status akreditasi dan lainnya. Uji hipotesis menyatakan Media Promosi Online tidak berdampak secara signifikan terhadap Keputusan Menjadi Mahasiswa Program Studi Manajemen STIE IPWIJA. Karena nilai $t$ hitung $(1,587)<t$ tabel $(1,661)$ atau Sig $(0,116)>$ a $(0,05)$ maka dapat disimpulkan Ho diterima dan Ha ditolak. Brand Images berdampak secara signifikan terhadap Keputusan Menjadi Mahasiswa Program Studi Manajemen STIE IPWIJA. Karena nilai $t$ hitung $(7,547)>t$ tabel $(1,661)$ atau Sig $(0,000)<$ a $(0,05)$ maka dapat disimpulkan Ho ditolak dan Ha diterima. Harga berdampak secara signifikan terhadap Keputusan Menjadi Mahasiswa Program Studi Manajemen STIE IPWIJA. Karena nilai $t$ hitung $(4,044)>t$ tabel $(1,661)$ atau Sig $(0,000)<$ a $(0,05)$ maka dapat disimpulkan Ho ditolak dan Ha diterima.
\end{abstract}

Kata Kunci: media promosi online, brand images, harga, keputusan

\section{PENDAHULUAN}

Proses perkembangan teknologi yang semakin tinggi, seperti penggunaan internet sudah sangat familier untuk memasarkan suatu produk. Kegiatan usaha yang dilakukan untuk melakukan pemasaran produk barang atau jasa dengan melalui media internet dapat disebut juga e-marketing. E-marketing adalah sisi pemasaran dari e-commerce, 
yang terdiri dari kerja dari perusahaan untuk mengkomunikasikan sesuatu, mempromosikan, dan menjual barang dan jasa melalui internet.

E-commerce adalah sistem penjualan yang berkembang setelah ditemukan Internet. Sistem pemasaran atau penjualan seperti ini bisa menjangkau seluruh dunia pada saat yang bersamaan tanpa harus mendirikan kantor cabang di semua negara. Selain itu juga bisa dilakukan 24 jam tanpa berhenti. Dengan hanya melalui unit komputer yang terhubung ke Internet, perusahaan dapat memasarkan produk-produknya (Arifin, 2003: 101).

Pemasaran dengan media promosi melalui internet khususnya dengan media online dapat menawarkan produk baik barang dan atau jasa secara luas dengan biaya pemasaran yang rendah. Konsumen dengan mudah untuk mengakses informasi mengenai produk yang ingin mereka cari dan beli karena tidak perlu tatap muka secara langsung.

Meningkatnya masyarakat mengakses media online di Indonesia melalui smartphones, bisa menjadi peluang promosi yang baik, salah satunya di bidang pendidikan. Laporan Tetra Pak Index 2017 yang belum lama diluncurkan, mencatatkan ada sekitar 132 juta pengguna internet di Indonesia. Sementara hampir setengahnya adalah penggila media sosial, atau berkisar di angka $40 \%$.

Angka ini meningkat lumayan dibanding tahun lalu, di 2016 kenaikan penguna internet di Indonesia berkisar $51 \%$ atau sekitar 45 juta pengguna, diikuti dengan pertumbuhan sebesar $34 \%$ pengguna aktif media sosial. Sementara pengguna yang mengakses sosial media melalui mobile berada di angka 39\%. Kembali ke 2017, Tetra Pak Index juga mengungkap bahwa tercatat ada lebih dari 106 juta orang Indonesia menggunakan media sosial tiap bulannya. Di mana $85 \%$ di antaranya mengakses sosial media melalui perangkat seluler.

Di dalam persaingan pasar, sebagai lembaga pendidikan, STIE IPWIJA selalu berusaha menempatkan posisi yang sangat strategis dan mudah dijangkau oleh masyarkat sekitar, sehingga memiliki brand images yang baik di benak konsumen. Dengan harga atau biaya perkuliahan yang terjangkau sehingga hal tersebut dapat menjadi daya pikat tersendiri untuk komsumen mengambil keputusan berkuliah. Sehingga media promoi online sebagai sarana tepat untuk menginformasikan kepada konsumen mengenai gambaran tentang STIE IPWIJA dan biaya kuliah.

Berdasarkan uraian di atas tersebut, maka peneliti melakukan pengkajian yang lebih mendalam tentang dampak media promosi online, brand images dan harga terhadap keputusan menjadi mahasiswa program sarjana manajemen STIE IPWIJA.

\section{TUJUAN PENELITIAN}

1. Apakah Media Promosi Online berdampak terhadap Keputusan Menjadi Mahasiswa Program Sarjana Manajemen STIE IPWIJA.

2. Apakah Brand Image berdampak terhadap Keputusan Menjadi Mahasiswa Program Sarjana Manajemen STIE IPWIJA.

3. Apakah Harga berdampak terhadap Keputusan Menjadi Mahasiswa Program Sarjana Manajemen STIE IPWIJA.

\section{TELAAH LITERATUR DAN PENGEMBANGAN PROPOSISI/HIPOTESIS Promosi Online}

E-marketing merupakan suatu
usaha dalam menyampaikan informasi, berkomunikasi, melakukan promosi, serta menjual produk dan jasa dengan menggunakan internet (Kotler dan Keller, 2008:153). Menurut Ramsunder (2011:7) e-marketing merupakan penggunaan sumber media elektronik sebagai media utama dalam pemasaran, misalnya penggunaan internet. Pendapat lain disampaikan Hooda dan Aggarwal (2012:108) yang mendefinisikan emarketing sebagai pemasaran produk 
dan jasa dengan menggunakan media elektronik. Menurut Boone dan Kurtz (2005:87), e-marketing adalah salah satu komponen dalam e-commerce dengan kepentingan khusus dari oleh marketer, yakni strategi proses pembuatan, pendistribusian, promosi, dan penetapan harga barang dan jasa kepada pangsa pasar internet atau melalui peralatan digital lain.

\section{Indikator dalam Promomosi Online}

Indikator yang mencirikan promosi yang digunakan dalam penelitian ini, yaitu (Kotler, 1996):

1. Jangkauan promosi

2. Kuantitas penayangan iklan di media promosi

3. Kualitas penyampaian pesan dalam penayangan iklan di media promosi.

\section{Brand Images}

Brand image merupakan hasil dari pandangan atau penelitian konsumen terhadap suatu brand baik atau buruk. Hal ini berdasarkan pertimbangan dengan membandingkan perbedaan yang terdapat pada beberapa brand, sehingga brand yang penawarannya sesuai dengan kebutuhan akan terpilih. Dapat disimpulkan bahwa citra merek (brand image) adalah suatu persepsi yang muncul pada benak konsumen terhadap suatu produk atau jasa ketika konsumen mengingat merek produk atau jasa tersebut.

Peter \& Olson (dalam Lutiary Eka Ratri, 2007: 47) Citra merek didefinisikan sebagai pandangan konsumen terhadap suatu merek, sebagaimana yang direfleksikan oleh berbagai macam asosiasi merek yang ada dalam ingatan konsumen.

\section{Indikator Brand Images}

Menurut Sutisna dalam jurnal penelitian, (Restu Setiawan, 2017:30) bahwa brand image memiliki tiga variabel pendukung, yaitu:

1. Citra Pembuat atau Perusahaan (Corporate Image) merupakan sekumpulan asosiasi yang dipersepsikan konsumen terhadap perusahaan yang membuat suatu produk atau jasa.
2. Citra Pemakai (User Image) merupakan sekumpulan asosiasi yang dipersepsikan konsumen terhadap pemakai yang menggunakan suatu barang atau jasa.

3. Citra Produk (Product Image) merupakan sekumpulan asosiasi yang dipresepsikan konsumen terhadap suatu produk.

\section{Harga}

Harga (price) adalah jumlah semua nilai yang diberikan oleh pelanggan untuk mendapatkan keuntungan dari memiliki atau menggunakan suatu produk atau jasa (Philip Kolter, 2008:345).

Menurut Basu Swastha (2005:185) harga adalah jumlah uang (ditambah beberapa barang kalau mungkin) yang dibutuhkan untuk mendapatkan sejumlah kombinasi dari barang beserta pelayanannya.

\section{Indikator Harga}

Menurut Kotler dan Armstrong (2008:278) yang diterjemahkan oleh Sabran ada empat indikator yang mencirikan harga yaitu:

1. Keterjangkauan harga: Harga yang diberikan oleh perusahaan terhadap produk mereka dapat dijangkau oleh para konsumennya. Harga yang sesuai dan terjangkau tentunya akan menjadi pertimbangan konsumen untuk membeli produk mereka.

2. Kesesuaian harga dengan kualitas produk: Harga yang diberikan oleh perusahan terhadap produknya sesuai dengan kualitas produk yang mereka hasilkan, misalnya jika harganya tinggi maka kualitas produk yang diberikan pun memiliki kualitas yang tinggi sehingga konsumen pun merasa tidak keberatan jika membeli produk tersebut.

3. Daya saing harga: Dalam pasar, perusahaan sebaiknya juga memperhatikan bahwa harga yang diberikan memiiki daya saing yang tinggi terhadap para kompetitornya. Jika harga yang 
diberikan terlampau tinggi di atas harga para kompetitor maka produk tersebut tidak memiliki daya saing yang baik.

4. Kesesuaian harga dengan manfaat: Manfaat produk yang dimiliki harus sesuai dengan harga yang diberikan oleh perusahaan terhadap produk mereka. Ada baiknya jika harga yang tinggi memiliki manfaat produk yang tinggi pula.

\section{Keputusan}

Pengambilan keputusan menurut Geoge R. Terry adalah pemilihan alternatif prilaku (kelakuan) dari dua atau lebih alternative yang ada. Menurut James A.F. Stoner, keputusan adalah pemilihan di antara berbagai alternatif. Definisi ini mengandung tiga pengertian, yaitu: (1) ada pilihan atas dasar logika atau pertimbangan; (2) ada beberapa alternatif yang harus dipilih salah satu yang terbaik; dan (3) ada tujuan yang ingin dicapai dan keputusan itu makin mendekatkan pada tujuan tersebut. Pengertian keputusan yang lain dikemukakan oleh Prajudi Atmosudirjo bahwa keputusan adalah suatu pengakhiran daripada proses pemikiran tentang suatu masalah dengan menjatuhkan pilihan pada suatu alternatif.

\section{Indikator Keputusan}

Proses pengambilan keputusan individu, di dampaki oleh faktor kebudayaan, faktor sosial, faktor pribadi dan faktor psikologis:

1. Faktor Kebudayaan: Faktor ini mempunyai banyak dampak yang paling luas dan paling dalam terhadap pengambilan keputusan dalam memilih tempat perkuliahan. Budaya adalah keseluruhan system gagasan, tindakan dan hasil karya manusia dalam rangka kehidupan masyarakat yang dijadikan diri dengan belajar. Budaya merupakan hasil kretivitas manusia dari satu generasi ke genaerasi berikutnya yang sangat menentukan perilaku dalam kehidupanya sebagai anggota masyarakat. Kebudayaan merupakan suatu yang komplek yang mencangkup ilmu pengetahuan, kepercayaaan seni, moral, adat, kebiasaa, dan normanorma yang berlaku pada masyarakat.

2. Faktor Sosial: Faktor ini meliputi faktor sosial seperti kelompok acuan, keluarga. Peran dan status sosial individu dan lingkungan sosial individu.

3. Faktor Keluarga: Menurut kamus besar Indonesia keluarga diartikan sebagai ibu bapak dengan anakanaknya, satuan kekerabatan yang sangat mendasar di masyarakat. Keluarga merupakan kelompok primer yang paling penting dalam masyarakat. Keluarga merupakan group yang terbentuk dari hubungan laki-laki dengan wanita. Hubungan yang sedikit banyak berlangsung lama untuk mencptakan dan membesarkan anak-anak. Bisa dikatakan bahwa keluarga dalam bentuk murni merupakan satu kesatuan sosial yang terdiri dari suami, istri dan anak-anak. Sesorang tidak bisa lepas dari dampak keluaga. Remaja membutuhkan nasehat untuk membantu mereka dalam mengambil keputusan dalam hidup mereka.

Faktor Pribadi: Karakteristik seseorang juga memdampaki keputusan remaja memilih putus sekolah, seperti gaya hidup dan konsep diri yang bersangkutan. Konsep diri (self consep) dan Gaya Hidup.

\section{Kerangka Pemikiran}

Berdasarkan teori tentang promosi online, brand images dan harga yang telah dikemukakan di atas, maka dengan ini peneliti menetapkan bahwa keputusan menjadi mahasiswa sangat didampaki oleh promosi online, brand images dan harga yang telah diterapkan oleh STIE IPWIJA. Oleh karena itu, berdasarkan uraian di atas untuk itu perlu menganalisa terlebih dahulu tentang promosi online, brand images dan harga berdasarkan kajian teori yang ada sehingga dapat diketahui dampaknya terhadap keputusan menjadi mahasiswa. Dampak antar 
variabel dalam penelitian ini dapat digambarkan sebagai berikut:

Gambar 1

Kerangka/Konstelasi

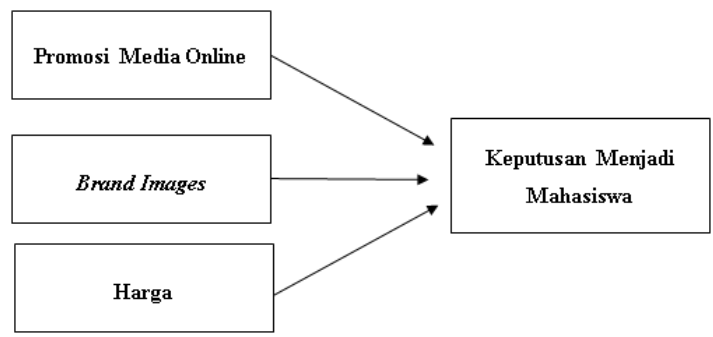

H1: Promosi Media Online berdampak terhadap keputusan menjadi Mahasiswa Pada Program Sarjana Manajemen STIE IPWIJA.

H2: Brand image berdampak terhadap keputusan menjadi Mahasiswa Pada Program Sarjana Manajemen STIE IPWIJA.

H3: Harga berdampak terhadap keputusan menjadi Mahasiswa Pada Program Sarjana Manajemen STIE IPWIJA.

\section{METODE PENELITIAN}

Penelitian ini dilakukan di kampus STIE IPWIJA di Tebet, Cikeas dan Baping Ciracas.

\section{Sampel Penelitian}

Sampel yang diambil dari populasi yang ada menggunakan rumus slovin didapat jumlah sebanyak 100 responden yang berasal dari mahasiswa angkatan $2017 / 2018$ semester genap dan mahasiswa angkatan 2018/2019 semester ganjil. Alasan kenapa sampelnya dua angkatan tersebut karena mulai penerapan media promosi online pada dua angkatan tersebut.

\section{Desain Penelitian}

Penelitian ini merupakan penelitian survei, dimana informasi yang dikumpulkan dari responden menggunakan kuesioner. Menurut Sugiyono (2008), penelitian survei ini pengumpulan data yang dilakukan menggunakan istrumen kuesioner/wawancara untuk mendapatkan tanggapan dari responden.

Dalam penelitian ini terdapat 4 variabel. Yaitu 3 variabel bebas atau $X$ dan 1 variabel terikat atau Y. Variabel bebas pertama yaitu promosi online (X1), variabel bebas ke dua yaitu brand images (X2), dan variabel ke tiga harga (X3). Satu variabel terikat yaitu keputusan (Y).

\section{Operasional Variabel}

Tabel 1

Indikator Variabel Penelitian

\begin{tabular}{|c|c|c|}
\hline Variabel & Indikator & Interval \\
\hline $\begin{array}{l}\text { Promosi } \\
\text { Onine (X1) } \\
\text { Menurut } \\
\text { Thoyibie } \\
\text { (2010), social } \\
\text { media } \\
\text { adalah } \\
\text { konten berisi } \\
\text { informasi, } \\
\text { yang dibuat } \\
\text { oleh orang } \\
\text { yang } \\
\text { memanfaat } \\
\text { kan } \\
\text { teknologi } \\
\text { penerbitan, } \\
\text { sangat } \\
\text { mudah } \\
\text { diakses dan } \\
\text { dimaksudka } \\
\text { n untuk } \\
\text { memfasilitasi } \\
\text { komunikasi, } \\
\text { dampak dan } \\
\text { interaksi } \\
\text { dengan } \\
\text { sesama dan } \\
\text { dengan } \\
\text { khalayak } \\
\text { umum. }\end{array}$ & \begin{tabular}{|l} 
1. Jangkauan \\
promosi \\
2. \\
Kuantitas \\
Penayang \\
an iklan di \\
media \\
promosi \\
3. \\
Kualitas \\
penyampai \\
an pesan \\
dalam \\
penayang \\
an iklan di \\
media \\
online.
\end{tabular} & $\begin{array}{l}\text { Interval } \\
1-5\end{array}$ \\
\hline $\begin{array}{l}\text { Brand } \\
\text { Images } \\
\text { (X2) Peter \& } \\
\text { Olson (dalam } \\
\text { Lutiary Eka } \\
\text { Ratri, 2007: } \\
\text { 47) Citra } \\
\text { merek } \\
\text { didefinisikan } \\
\text { sebagai }\end{array}$ & 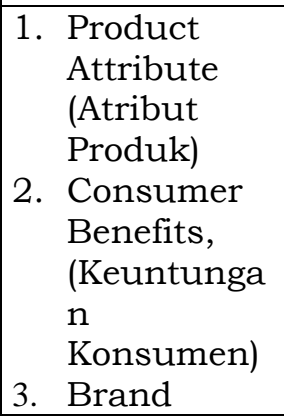 & $\begin{array}{l}\text { Interval } \\
1-5\end{array}$ \\
\hline
\end{tabular}




\begin{tabular}{|c|c|c|}
\hline $\begin{array}{l}\text { pandangan } \\
\text { konsumen } \\
\text { terhadap } \\
\text { suatu merek, } \\
\text { sebagaimana } \\
\text { yang } \\
\text { direfleksikan } \\
\text { oleh } \\
\text { berbagai } \\
\text { macam } \\
\text { asosiasi } \\
\text { merek yang } \\
\text { ada dalam } \\
\text { ingatan } \\
\text { konsumen. }\end{array}$ & $\begin{array}{l}\text { Personality, } \\
\text { (Kepribadi } \\
\text { an Merek). }\end{array}$ & \\
\hline $\begin{array}{l}\text { Harga (X3) } \\
\text { Harga } \\
\text { adalah } \\
\text { satuan } \\
\text { moneter } \\
\text { atau ukuran } \\
\text { lainnya } \\
\text { termasuk } \\
\text { barang dan } \\
\text { jasa lainnya } \\
\text { yang } \\
\text { ditukarkan } \\
\text { agar } \\
\text { memperoleh } \\
\text { hak } \\
\text { kepimilikan } \\
\text { atau } \\
\text { pengguna } \\
\text { suatu } \\
\text { barang dan } \\
\text { jasa. } \\
\text { Tjiptono } \\
\text { (2005) }\end{array}$ & $\begin{array}{ll}\text { 1. } & \text { Keterjang } \\
\text { kauan } \\
\text { Harga } \\
\text { 2. }\end{array}$ & $\begin{array}{l}\text { Interval } \\
1-5\end{array}$ \\
\hline $\begin{array}{l}\text { Keputusan } \\
\text { (Y) }\end{array}$ & $\begin{array}{l}\text { Proses } \\
\text { pengambilan } \\
\text { keputusan } \\
\text { individu, } \\
\text { dipengaruhi } \\
\text { oleh } \\
\text { 1. faktor } \\
\text { kebudayaan, } \\
2 . \quad \text { faktor } \\
\text { sosial, } 3 . \\
\text { faktor pribadi } \\
\quad \text { dan } \\
\text { 4.faktor psikologis. } \\
\quad \text { Kotler }\end{array}$ & $\begin{array}{l}\text { Interval } \\
1-5\end{array}$ \\
\hline
\end{tabular}

\section{Metode Analisis}

Analisis yang digunakan dalam penelitian ini adalah model persamaan linier berganda sebagai berikut: $\mathrm{Y}=\mathrm{a}+$ $\mathrm{bX} 1+\mathrm{bX} 2+\mathrm{bX} 3$

Dimana:

$\mathrm{Y}=$ Subjek variabel terikat yang diproyeksikan

$\mathrm{a}=$ Nilai konstanta

$\mathrm{b}=$ Nilai arah sebagai penentu ramalan variabel Y

$\mathrm{x}=$ Variabel bebas yang mempunyai nilai

\section{Rancangan Pengujian}

Uji validitas dan reliabilitas, uji asumsi klasik (uji normalitas, uji multikolinieritas, uji heteroskedastisitas, uji auto korelasi), analisis regresi berganda, koefisien determinasi R2, uji hipotesis (uji t dan uji parsial f).

\section{HASIL DAN PEMBAHASAN Hasil Penelitian}

Dari uji validitas terhadap masingmasing variabel penelitian ditemukan bahwa semua item pertanyaan dalam kuesioner penelitian mempunyai koefisien korelasi $r$ hitung yang lebih besar dari $r$ tabel $=0,197$ sehingga item pertanyaan tersebut valid.

Melalui uji reliabilitas ditemukan bahwa keseluruhan variabel memiliki Cronbach Alpha yang lebih besar dari 0,197, sehingga variabel penelitian ini dapat dibuktikan reliabilitasnya. Karena kuesioner telah valid dan reliabel maka kuesioner penelitian merupakan alat yang handal untuk mengukur masingmasing variabel penelitian.

Penelitian ini menghasilkan model persamaan $\mathrm{Y}=2,896+0,107 \mathrm{X} 1+0,498$ $\mathrm{X} 2+0,317 \mathrm{X} 3$. F hitung sebesar 68,246, sementara $\mathrm{F}$ tabel dengan $\mathrm{df}=100-2-1=$ 97 didapat sebesar 2,700. Nilai $F$ hitung lebih besar dari $\mathrm{F}$ tabel, maka dengan demikian model regresi layak untuk dapat menjelaskan Dampak Media Promosi Online, Brand Image dan Harga Terhadap Keputusan Menjadi Mahasiswa Program Sarjana Manajemen STIE IPWIJA dinyatakan fit atau baik. 


\section{Pengujian Hipotesis Uji Parsial (Uji t)}

1. Nilai $t$ hitung Dampak Media Promosi Online sebesar 1,587 sementara $\mathrm{t}$ tabel dengan sig. $\mathrm{a}=$ 0,05 dan $\mathrm{df}=\mathrm{n}-\mathrm{k}$ yaitu $100-2=98$, maka didapat $t$ tabel (one tail) sebesar 1,661. Nilai t hitung lebih kecil dibandingkan nilai t tabel, hal ini menunjukkan dan menyatakan tidak ada dampak Media Promosi Online terhadap Keputusan Menjadi Mahasiswa STIE IPWIJA.

2. Nilai t hitung Brand Images sebesar 7.547 sementara $t$ tabel dengan sig. $\mathrm{a}=0,05$ dan $\mathrm{df}=\mathrm{n}-\mathrm{k}$ yaitu $100-2=$ 98, maka didapat $\mathrm{t}$ tabel (one tail) sebesar 1,661. Nilai t hitung lebih besar dibandingkan nilai t tabel, hal ini menunjukkan dan menyatakan ada dampak Brand Images terhadap Keputusan Menjadi Mahasiswa STIE IPWIJA.

3. Nilai t hitung Harga sebesar 4.044 sementara $\mathrm{t}$ tabel dengan sig. $\mathrm{a}=$ 0,05 dan $\mathrm{df}=\mathrm{n}-\mathrm{k}$ yaitu $100-2=98$, maka didapat $t$ tabel (one tail) sebesar 1,661. Nilai t hitung lebih besar dibandingkan nilai t tabel, hal ini menunjukkan dan menyatakan ada dampak Harga terhadap Keputusan Menjadi Mahasiswa STIE IPWIJA.

\section{Pembahasan}

Penelitian mengenai Dampak Media Promosi Online, Brand Images dan Harga Terhadap Keputusan Menjadi Mahasiswa Program Studi Manajemen STIE IPWIJA, dapat dibuat pembahasannya sebagai berikut:

\section{Media Prmomosi Online Tidak} Berdampak Terhadap Peningkatan Jumlah Keputusan Menjadi Mahasiswa Program Sarjana Manajemen STIE IPWIJA.

Berdasarkan hasil analisa di atas menunjukan bahwa nilai $\mathrm{t}$ hitung Dampak Media Promosi Online sebesar 1,587 sementara $t$ tabel dengan sig. $\mathrm{a}=0,05$ dan $\mathrm{df}=\mathrm{n}-\mathrm{k}$ yaitu $100-2=98$, maka didapat $\mathrm{t}$ tabel (one tail) sebesar 1,661. Nilai t hitung lebih kecil dibandingkan nilai $\mathrm{t}$ tabel, hal ini menunjukkan dan menyatakan tidak ada dampak signifikan Media Promosi Online terhadap Keputusan Menjadi Mahasiswa STIE IPWIJA. Hasil yang didapat penelitian ini sesuai dengan hipotesis penelitian yang menyatakan bahwa Media Promosi Online tidak ada dampak signifikan terhadap pemingkatan jumlah Keputusan Menjadi Mahasiswa Program Studi Manajemen STIE IPWIJA. Hal ini tidak sejalan dengan penelitian terdahulu yang telah dilakukan oleh beberapa peneliti yang sudah tercantum pada bab 2 laporan penelitian ini, yaitu: Lancarya Prasetomo (2016) yang menjelaskan bahwa hasil dari penelitian ini menyatakan promosi online berdampak signifikan terhadap keputusan pembelian. Hal ini dikarenakan Media Promosi Online STIE IPWIJA baru saja beroperasi Desember 2017 sehingga belum memiliki dampak yang begitu besar terhadap keputusan menjadi mahasiswa dan belum semua media online dipergunakan sebagai sarana untuk promosi seperti Youtube, Path, SMS, Email Marketing dll. Disisi lain bisa jadi konten dan iklan promosi yang ada di media online dalam penyampaiannya belum terlalu maksimal.

2. Brand Images Berdampak Terhadap Peningkatan Jumlah Keputusan Menjadi Mahasiswa Program Sarjana Manajemen STIE IPWIJA.

Berdasarkan hasil analisa di atas menunjukan bahwa nilai $\mathrm{t}$ hitung Brand Images sebesar 7,547 sementara $\mathrm{t}$ tabel dengan sig. $\mathrm{a}=$ 0,05 dan $\mathrm{df}=\mathrm{n}-\mathrm{k}$ yaitu $100-2=98$, maka didapat $\mathrm{t}$ tabel (one tail) sebesar 1,661. Nilai t hitung lebih besar dibandingkan nilai t tabel, hal ini menunjukkan dan menyatakan ada dampak signifikan Brand Images terhadap Keputusan Menjadi Mahasiswa STIE IPWIJA. Hal ini sejalan dengan penelitian terdahulu yang telah dilakukan oleh beberapa peneliti yang sudah tercantum pada bab 2 laporan penelitian ini, yaitu: 
Frengki Yusuf (2018) yang menjelaskan bahwa Brand Image berdampak signifikan terhadap Keputusan Mendaftar Calon Mahasiswa. Artinya penelitian ini penting untuk menitik beratkan pada indikator yang digunakan peneliti dalam penelitian tentang dampak brand images terhadap keputusan menjadi mahasiswa. Untuk ini STIE IPWIJA perlu mempertahankan dan pengembangkan aspek-aspek yang dapat mengangkat brand images seperti lebih meningkatkan kualitas pendidikan yang lebih baik lagi dan selalu berorientasi kepada kewirausahaan. Terus melakukan pengembangan fasilitas sarana dan prasarana yang menunjang kegiatan perkuliahan, sehingga dapat menjadi daya tarik.

3. Harga Berdampak Terhadap Peningkatan Jumlah Keputusan Menjadi Mahasiswa Program Sarjana Manajemen STIE IPWIJA.

Berdasarkan hasil analisa diatas menunjukan bahwa nilai $t$ hitung Harga sebesar 4,044 sementara t tabel dengan sig. $\mathrm{a}=0,05 \mathrm{dan} \mathrm{df}=$ $\mathrm{n}-\mathrm{k}$ yaitu $100-2=98$, maka didapat t tabel (one tail) sebesar 1,661. Nilai $\mathrm{t}$ hitung lebih besar dibandingkan nilai $\mathrm{t}$ tabe, hal ini menunjukkan dan menyatakan ada dampak signifikan Harga terhadap Keputusan Menjadi Mahasiswa STIE IPWIJA. Hal ini sejalan dengan penelitian terdahulu yang telah dilakukan oleh beberapa peneliti yang sudah tercantum pada bab 2 laporan penelitian ini, yaitu: Corry Amelia (2015) yang menjelaskan bahwa Harga memiliki dampak positif dan signifikan terhadap keputusan pembelian. Demikian juga yang diutarakan Septiana Sri Hartanti (2015) yang menjelaskan bahwa harga memiliki dampak positif dan signifikan terhadap keputusan. Artinya penelitian ini penting untuk menitik beratkan pada indikator yang digunakan peneliti dalam penelitian tentang dampak harga terhadap keputusan menjadi mahasiswa. Untuk itu STIE IPWIJA tetap menjaga kemudahan yang sudah ditawarkan kepada calon mahasiswa seperti diantaranya biaya kuliah yang ditawarkan sesuai dengan kualitas pelayanan yang diberikan. Tetap memberikan kemudahan dalam pembayaran SPP, uang gedung dengan cara diangsur.

\section{KESIMPULAN \\ Simpulan}

Hasil penelitian ini mengasilkan persamaan regresi linier berganda sebagai berikut:

$$
\mathrm{Y}=2,896+0,107 \mathrm{X} 1+0,498 \mathrm{X} 2+
$$
$0,317 \mathrm{X} 3$ dan nilai Adjust $\mathrm{R}$ Square sebesar 0,671. Sehingga peneliti dapat memberikan kesimpulan sebagai berikut:

1. Media Promosi Online tidak berdampak secara signifikan terhadap Keputusan Menjadi Mahasiswa Program Studi Manajemen STIE IPWIJA.

2. Brand Images berdampak secara signifikan terhadap Keputusan Menjadi Mahasiswa Program Studi Manajemen STIE IPWIJA.

3. Harga berdampak secara signifikan terhadap Keputusan Menjadi Mahasiswa Program Studi Manajemen STIE IPWIJA.

\section{Saran}

1. Untuk pihak Sekolah Tinggi Ilmu Ekonomi IPWI Jakarta hendaknya meningkatkan promosi di media online dengan lebih baik dan giat lagi. Gunakan seluruh aspek media online yang dapat memungkinkan sebagai sarana infomasi kegiatan dan iklan mengenai penerimaan mahasiswa baru, sehingga iklan yang ditayangkan atau di publikasikan dapat terjangkau dengan mudah oleh seluruh aspek masyarakat yang berasal dari berbagai kalangan dan memiliki jangkauan luas yang tidak terbatas. Adapun pemanfaatan media online selanjutnya yang adalah seperti Youtube sebagai sarana untuk 
informasi kegiatan dan iklan penerimaan mahasiswa dengan video atau film pendek, SMS sebagai sarana media promosi penerimaan mahasiswa baru, Path sebagai social media, Email Marketing dan lainnya. Serta lebih membuat iklan dan konten promosi semenarik mungkin agar mendapatkan respon yang lebih baik lagi.

2. STIE IPWIJA perlu mempertahankan dan pengembangkan aspek-aspek yang dapat mengangkat brand images seperti lebih meningkatkan kualitas pendidikan yang lebih baik lagi dan selalu berorientasi kepada kewirausahaan. Terus melakukan pengembangan fasilitas sarana dan prasarana yang menunjang kegiatan perkuliahan, sehingga dapat menjadi daya tarik. STIE IPWIJA tetap menjaga kemudahan yang sudah ditawarkan kepada calon mahasiswa seperti diantaranya biaya kuliah yang ditawarkan sesuai dengan kualitas pelayanan yang diberikan. Tetap memberikan kemudahan dalam pembayaran SPP, uang gedung dengan cara di angsur.

3. Untuk Peneliti Mendatang perlu dilakukan penelitian lebih lanjut terhadap faktor-faktor selain Media Promosi Online, Brand Images dan Harga Terhadap Keputusan Menjadi Mahasiswa Program Studi Manajemen STIE IPWIJA. Hal ini menunjukan bahwa sebesar sebesar $67,1 \%$ Variabel Media Promosi Online (X1), Brand Images (X2) dan Harga (X3) secara simultan bermahasiswa terhadap Keputusan Menjadi Mahasiswa Program Studi Manajemen STIE IPWIJA (Y), sedangkan sisa $32,9 \%$ didampaki variabel lain misalkan seperti lokasi, pelayanan, status akreditasi dan lainnya. Yang memungkinkan dapat memdampaki dan menyempurnakan hasil penelitian ini. Penelitian yang akan datang disarankan untuk mencari ruang lingkup populasi yang berbeda dan lebih luas dari populasi dalam penelitian ini, dengan demikian diperoleh lebih banyak dan optimal.

\section{DAFTAR PUSTAKA}

Arnot-Blog. III. (2016). Pengertian Harga Menurut Para Ahli. [On-line] http:/ / pengertianharga.blogspot.c om/2016/03/pengertian-hargamenurut-para ahli.html. Di akses 7 Juli 2019 Jam 16.00.

Boone, Louis E., and Kurtz, David L. (2005). Contemporary Marketing. Ohio: Thomson South Western.

Corry, Amelia. (2015). "Dampak Harga Terhadap Keputusan Pembelian Jasa Pelatihan (Studi Kasus pada Konsumen C\&G Training Training Network)". Skripsi Perpustakaan Sekolah Tinggi Ilmu Ekonomi IPWI Jakarta.

Gary, Armstrong, dan Kotler, Philip. (2008). Prinsip-Prinsip Pemasaran, Edisi 12. Jakarta: Erlangga.

Gozali, Imam. (2011). Aplikasi Analisis Multivariate dengan Program SPSS. Semarang: Badan Penerbit Universitas Diponegoro.

Hartanti, Sri Septiana. (2015). "Analisa Dampak Produk, Harga dan Promosi Terhadap Keputusan Pembelian Konsumen". (Studi kasu pada Outlet Zenius Education Jakarta. Skripsi Perpustakaan Sekolah Tinggi Ilmu Ekonomi IPWI Jakarta).

Kotler, Philip. (2010). Manajemen Pemasaran, Edisi tiga belas Bahasa Indonesia. Jilid 1 dan 2. Jakarta: Erlangga.

Kotler, Philip. (2009). Manajemen Pemasaran. Edisi tiga belas Bahasa Indonesia. Jilid 1 dan 2. Jakarta: Erlangga.

Kotler, Philip dan Keller, Kevin L. (2007). Manajemen Pemasaran, Edisi 12. Jakarta: Indeks.

Kusniawati. (2017). "Dampak Harga, Lokasi dan Promosi Terhadap Keputusan Pembelian Pada Alfamidi Jalan Blora Menteng Jakarta Pusat". Skripsi Perpustakaan Sekolah Tinggi Ilmu Ekonomi IPWI Jakarta.

Lancarya, Prasetomo. (2016). "Dampak Promosi Online Terhadap Keputusan Pembelian”. 
Mulyanto, Heru, dan Anna, W. (2010). Penelitian Metode dan Analisis. Semarang: CV. Agung.

Mursida. (2017). "Analisis Dampak Harga, Tempat dan Promosi Terhadap Keputusan Pembelian OOPS Di SEIBU" Skripsi Perpustakaan Sekolah Tinggi Ilmu Ekonomi IPWI Jakarta.

Riduwan, Adun, R. (2011). Cara Mudah Belajar SPSS 17.00 dan Aplikasi Statistik Penelitian.

Risyeddin, Lubis. (2015). "Dampak Harga, Promosi dan Lokasi Terhadap Keputusan Pembelian Produk PT. Sarinah Departement Store Jakarta". Tesis Perpustakaan Sekolah Tinggi Ilmu Ekonomi IPWI Jakarta.

STIE IPWIJA-Web. VI (2019). Struktur Organisasi STIE IPWIJA. [On-line] http://stieipwija.ac.id/homepage/struktur-organisasi-stieipwija. Di akses 7 Juli 2019 Jam 15.15.

STIE IPWIJA-Web. VI (2019). Visi Misi STIE IPWIJA. [On-line] http://stieipwija.ac.id/visi-misistie-ipwija. Di akses 7 Juli 2019 Jam 15.15.

The Manajemen Blog's. X (2009) Faktor yang Mendampaki Keputusan

Pembelian.

[On-line] https://ilmumanajemenpemasara n.wordpress.com /2009/10/31/fktr-pngarh-keppmblian/. Di akses 1 Juli 2019 Jam 09.00.

Tjiptono, Fandy. (2008). Strategi Pemasaran, Edisi 3. Yogyakarta: Andi.

Widyawati, Astarningrum (2013) "Dampak Harga, Promosi dan Kualitas Pelayanan Terhadap Keputusan Pembelian Majalah Tempo". Tesis Perpustakaan Sekolah Tinggi Ilmu Ekonomi IPWI Jakarta

Yudhianto-detik.com. IX (2017). 132 Juta Pengguna Internet Indonesia, $40 \%$ Penggila Medsos. [On-line] https://inet.detik.com/cyberlife/d3659956/132-juta-penggunainternet-indonesia-40-penggilamedsos. Di akses 20 Juni 2019 Jam 12.45 .

Yusuf, Frengki. (2018). "Dampak Promosi Dan Brand Image Sekolah Tinggi Ilmu Ekonomi IPWI Jakarta Terhadap Minat Mendaftar Calon Mahasiswa Di Kampus Utama Jalan Haji Baping Jakarta Timur". Skripsi Perpustakaan Sekolah Tinggi Ilmu Ekonomi IPWI Jakarta. 